\title{
Quality System Audits of the Finnish Universities from the e-Learning Perspectives
}

\author{
Pekka Kess
}

M3S, University of Oulu, Finland \& School of Technology and Innovations, Production, University of Vaasa, Finland Corresponding author.Email: pekka.kess@gmail.com

\begin{abstract}
Digitalization has been an increasing trend in the last 20 years even in Finnish universities. Several attempts have been made systematize eLearning development in all universities. Finland has 14 universities, and they all follow the Bologna process guidelines where quality assurance is one cornerstone. There is a national quality audit organization - Finnish Education Evaluation Centre (FINEEC) who is charge of conducting quality management system audits in universities. The audit reports are good source of information about the status of quality assurance in each of the universities. A document analysis was carried out to 19 quality management system audits and the results show that:

1.Universities have taken internet to use in education usage for education in some forms.

2.Universities have various IT systems in use for teaching and learning purposes. It seems that most universities have developed their own systems in addition to utilizing Moodle teaching and learning platform.

3. A couple of universities have indicated support functions for the use of eLearning both for the teachers and students.

4.All universities have quality management systems but none of the universities have presented quality assurance practices beyond student feedback, but no explanations how the student feedback is actually used to improve the quality of the teaching in these universities.
\end{abstract}

Keywords: eLearning, quality assurance, document analysis, audit, Bologna process.

\section{INTRODUCTION}

\subsection{The Finnish University System}

The Finnish higher education system consists of universities and universities of applied sciences. After some mergers in the past decades a total of 13 universities and 22 universities of applied sciences operates in the Ministry of Education and Culture's administrative branch. Higher education degrees in the military sector are completed at the Finnish National Defence University, which operates under the defence administration. The universities in Finland are as follows [1]:

\begin{tabular}{|l|l|l|}
\hline $\begin{array}{l}\text { Aalto } \\
\text { University }\end{array}$ & LUT University & $\begin{array}{l}\text { University of } \\
\text { Turku }\end{array}$ \\
\hline $\begin{array}{l}\text { University of } \\
\text { Helsinki }\end{array}$ & $\begin{array}{l}\text { University of } \\
\text { Oulu }\end{array}$ & $\begin{array}{l}\text { University of } \\
\text { Vaasa }\end{array}$ \\
\hline $\begin{array}{l}\text { University of } \\
\text { Eastern Finland }\end{array}$ & $\begin{array}{l}\text { Hanken School } \\
\text { of Economics }\end{array}$ & $\begin{array}{l}\text { Abo Akademi } \\
\text { University }\end{array}$ \\
\hline
\end{tabular}

\begin{tabular}{|l|l|l|}
\hline $\begin{array}{l}\text { University of } \\
\text { Jyväskylä }\end{array}$ & $\begin{array}{l}\text { University of } \\
\text { the Arts }\end{array}$ & $\begin{array}{l}\text { National } \\
\text { Defence } \\
\text { University }\end{array}$ \\
\hline $\begin{array}{l}\text { University of } \\
\text { Lapland }\end{array}$ & $\begin{array}{l}\text { Tampere } \\
\text { University }\end{array}$ & \\
\cline { 1 - 2 } &
\end{tabular}

The basic task of the universities is to engage in scientific research and provide the highest level of education based on it. Universities promote lifelong learning, interact with society and promote the societal impact of research results and artistic activities. To guarantee the freedom of science, the arts and higher education, universities are autonomous actors. Universities are independent legal entities that have the right to make independent decisions on matters related to their internal administration. [1]

\subsection{Quality issues from the Bologna Agreement}

Formally the Bologna process started with the Bologna declaration in 1999. The Declaration was signed by 29 European countries. The aim for the European 
states with this declaration was to establish a European Higher Education Area. One corner stone of the declaration was the Quality Assurance for the European higher education. With the declaration the European states would coordinate their higher education policies in various ways like [2]

- adapting comparable degrees in higher education

- establishment of two cycle education system with undergraduate and graduate studies

- establishment of the credit transfer system for student mobility

- promotion of cooperation in the area of quality assurance to develop comparable criteria and methodologies.

The Bologna process progress resulted results by 2012 so that most European countries had accommodated their higher education degrees to three levels: bachelor, master and doctoral. Likewise, most countries had developed their quality assurance structures at national and European levels. Through the process the role of the quality assurance organization in each of the member states has changed. Originally the aim was to have an independent accreditation agency in each of the member states. Some countries applied it that way, but some countries like Finland, established an agency inside the ministry of education. [2]

Higher education institutions themselves have the primary responsibility for the quality of education they organize. This is stipulated in the Finnish Universities Act and the universities are responsible for evaluating their education, research and artistic activities. [3]

The acts also state that HEIs must regularly participate in external evaluations. These are mainly carried out by the Finnish Education Evaluation Centre (FINEEC) which was established in 2014 and it continues as an agency responsible for the national evaluation of education. Until 2014 external evaluations were carried by the Finnish Higher Education Evaluation Council (FINHEEC). FINEEC was formed by combining the evaluation activities of FINHEEC and those of the Finnish Education Evaluation Council and the Finnish National Board of Education.

FINEEC declares to be independent, but the funding comes from the Ministry of the Education and Culture like the funding to the universities as well. The external evaluation in higher education has an advisory orientation not accreditation. It aims at involving staff, students and stakeholders of the HEI in recognising strengths, good practices and development areas. The goal is also to support HEIs in achieving their own objectives and this way support the continuous development of higher education. [3]

The tasks of the FINEEC include [3]:
- evaluating education, teaching, education providers, and the activities of higher education institutions,

- developing the evaluation of education,

- evaluating learning outcomes in basic education, upper secondary education and training and basic education in arts,

- supporting education providers and higher education institutions in matters related to evaluation and quality management,

- undertaking evaluations of learning outcomes in basic education, upper secondary education and training, and basic education in the arts.

The Ministry of Education and Culture appoints the Higher Education Evaluation Committee that operates in connection with FINEEC. The Committee decides on project plans for the evaluations of HEIs, the composition of planning and review teams, and the final results of the audits. FINEEC is a member of the European Quality Assurance Register for Higher Education (EQAR) and a full member of the European Association for Quality Assurance in Higher Education (ENQA). [3]

\section{3. eLearning defined}

Koponen [4] defines eLearning as the 'utilisation of the ICT in learning in order to acquire, process and store information as well as to develop these ICT utilisation abilities when the learner acts in reality observing, contemplating, communicating, acquiring and exchanging information, as well as in this reality getting and exchanging experiences by using his/her know-how in everyday work and leisure activities'.

From this perspective, eLearning can be assessed from various points of view. The pedagogical dimension of eLearning refers to teaching and learning. This dimension addresses issues that concern analysis of content, audiences and goals, as well as media analysis, design approaches and the organisation, methods and strategies of eLearning environments. The technological dimension of eLearning, in contrast, examines issues of technology infrastructure in eLearning environments. This would include infrastructure planning, hardware and software. The interface dimension refers to the overall look and feel of the eLearning delivery and encompasses site design, content design, navigation and usability testing. The evaluation of eLearning includes both the assessment of learners and evaluation of the instruction and the learning environment. The management of eLearning refers to the management of the organisation(s) responsible for the eLearning delivery. The resource support dimension of eLearning examines the online support and resources required to foster meaningful learning environments. The ethical considerations of eLearning relate to social and political 
influences, cultural diversity, biases, geographical diversity, learner diversity, information accessibility, etiquette and the legal issues. The institutional dimension is concerned with issues of administrative affairs, academic affairs and student services related to eLearning. The institutional issue also determines how eLearning is integrated into the educational and research used for online learning; a fact that makes it difficult to develop a generic definition'.

\subsection{Digitalization of the Finnish higher education}

The Ministery of Education defined its first ICT

Table 1. Digital platforms in Finnish universities

\begin{tabular}{|c|c|c|c|c|c|c|c|c|c|c|c|c|c|c|}
\hline & 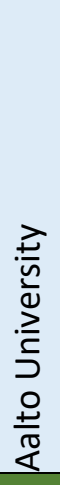 & 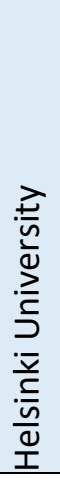 & 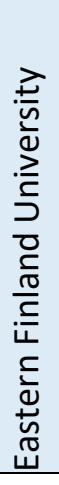 & 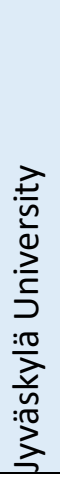 & 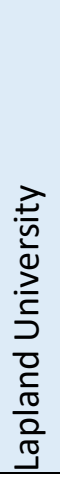 & 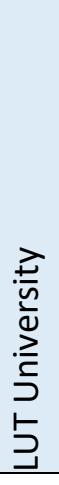 & 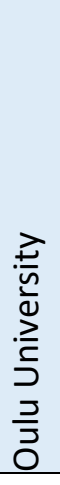 & 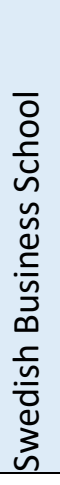 & 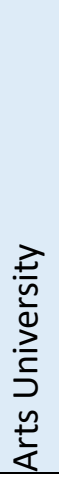 & 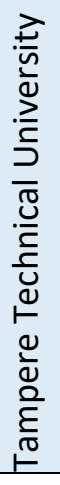 & 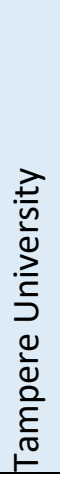 & 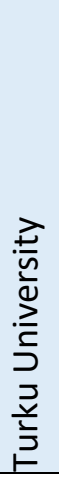 & 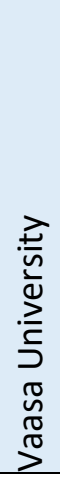 & 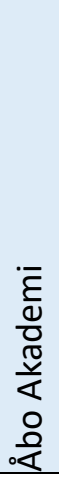 \\
\hline Aalto Op & & & & & & & & & & & & & & \\
\hline Adope Cc & & & & & & & & & & & & & & \\
\hline Blogs & & & & & & & & & & & & & & \\
\hline Canvas & & & & & & & & & & & & & & \\
\hline Echo360 & & & & & & & & & & & & & & \\
\hline Google C & & & & & & & & & & & & & & \\
\hline iLinc & & & & & & & & & & & & & & \\
\hline Koppa & & & & & & & & & & & & & & \\
\hline Moodle & & & & & & & & & & & & & & \\
\hline MyCours & & & & & & & & & & & & & & \\
\hline 0365 & & & & & & & & & & & & & & \\
\hline OPTIMA & & & & & & & & & & & & & & \\
\hline Pedanet & & & & & & & & & & & & & & \\
\hline REAL & & & & & & & & & & & & & & \\
\hline Skype & & & & & & & & & & & & & & \\
\hline TIM & & & & & & & & & & & & & & \\
\hline ViLLE & & & & & & & & & & & & & & \\
\hline Wiki & & & & & & & & & & & & & & \\
\hline Yammer & & & & & & & & & & & & & & \\
\hline
\end{tabular}

work of the university.

The eLearning literature (both electronically published and traditionally printed) is expanding at a great speed. Still - or maybe because of the great interest - the terminology remains somewhat unclear. Many related and overlapping definitions are used. Ally [5] states it this way: 'Different terminologies have been strategy for the period of 1995-1999. A new version was defined for the period of 2000-2004. This strategy asked all schools to have their own ICT strategies by 2002. [6] From the higher education digitalization points of view the establishing of the Finnish Virtual University (FVU) was a significant move forward. The development of a virtual university was a stated aim in the national strategy for Education, Training and Research in the Information 
Society 2000-2004 and in the Information Society Programme for Education, Training and Research 20042006.

After about 5 years of development the FVU the key areas of operations were:

- promoting student mobility: negotiating a nationwide agreement on flexible study rights, providing online information services,

- quality assurance in online education: developing tools and systems,

- online learning materials and learning objectives: developing functional exchange systems,

- teacher training in ICT: courses for university staff and local experts at universities,

- Web tools for planning and evaluating online education.

The FVU closed its operation by 2010 based on the consortium agreement. [7]

By 2016 the Finnish universities had established very extensively digital platforms for educational purposes. Tikkanen [8] collected rather comprehensive list of those platforms in table 1 . The list is not complete, but it shows the multitude of the software systems applied by the universities at that time. Another inventory of the ICT systems in use in Finnish higher education institutions came to a total number of close to one thousand different ICT systems for research, education and administration.

\section{RESEARCH}

Research question in this study is: "How is the eLearning taken into account in the quality system audits of the Finnish universities?"

To answer the research question, the used research method is document analysis of the audit reports of the Finnish universities. All Finnish universities have gone through the external evaluation of their quality system.
The analysis is used to identify eLearning elements in each of them. Based on information available (like the Table 1) we can assume that eLearning is well present in the Finnish universities. Document analysis is a systematic procedure for reviewing or evaluating documents - both printed and electronic materials can and will be used. All quality systems audits have been reported so far by the Finnish Education Evaluation Centre and they are publicly available. Data analysis as a research method is efficient. It is less time-consuming and requires data selection, instead of data collection. [9]

A total of 19 quality system audit reports were analysed in order to answer the research question. Special attention was given:

- internet usage for education,

- data systems to support teaching and learning,

- support functions for the use of eLearning,

- quality assurance practices.

\section{RESULTS}

Very compact presentation of the findings is presented in table 2 below. The results show that most universities have taken internet to use in education usage for education in some forms. They also show that universities have taken various IT systems into use for teaching and learning purposes. It seems that most universities have developed their own systems in addition to utilizing Moodle teaching and learning platform.

A couple of universities have indicated support functions for the use of eLearning both for the teachers and students.

All universities have quality management systems but none of the universities have presented quality assurance practices beyond student feedback, which seems to be the only quality element in use. However there has been no explanations how the student feedback is actually used to improve the quality of the teaching in these universities.

Table 2. Digital platforms in Finnish universities

\begin{tabular}{|l|c|l|}
\hline University & $\begin{array}{l}\text { Year } \\
\text { of the } \\
\text { audit }\end{array}$ & eLearning aspects \\
\hline $\begin{array}{l}\text { Aalto } \\
\text { University }\end{array}$ & 2016 & $\begin{array}{l}\text { Online systems are used extensively to manage, communicate and support the } \\
\text { quality processes. } \\
\text { The education provision is primarily managed and communicated to students } \\
\text { and staff online OPIT-wiki is used as the gateway to resources and for sharing } \\
\text { information about learning and student information systems. } \\
\text { The primary learning platform will be accessed via My Courses and OpasOodi } \\
\text { will become the main database repository for course descriptions. }\end{array}$ \\
\hline
\end{tabular}




\begin{tabular}{|c|c|c|}
\hline & & $\begin{array}{l}\text { Blended learning, a combination of face-to-face and online teaching, is one } \\
\text { method used to promote interaction and personalized contacts between } \\
\text { students and the faculty. } \\
\text { Technical and pedagogical support is available to assist teachers in } \\
\text { implementing new interactive methods. [10] }\end{array}$ \\
\hline $\begin{array}{l}\text { University } \\
\text { of Helsinki }\end{array}$ & 2015 & $\begin{array}{l}\text { The Department of Computer Science employs a large variety of teaching } \\
\text { methods and encourages the use of ICT tools as support for learning. An } \\
\text { increasing share of the teaching is based on online courses and e-learning as a } \\
\text { way to foster innovative and creative teaching outside the traditional } \\
\text { boundaries. The introduction of MOOCs is a strong indication of such } \\
\text { commitment. [11] }\end{array}$ \\
\hline $\begin{array}{l}\text { University } \\
\text { of Eastern } \\
\text { Finland }\end{array}$ & 2017 & $\begin{array}{l}\text { Digi Steering Group is developing a new online work environment, together } \\
\text { with the communication tool Yammer - both tools are expected to enhance } \\
\text { information on quality issues irrespective of time and place. } \\
\text { A renewed feedback system description is being completed, and the } \\
\text { opportunity for students' counter feedback is being developed in the OODI } \\
\text { system } \\
\text { Students expressed their reluctance towards online course evaluations. } \\
\text { There are also separate courses available on quality issues, such as the online } \\
\text { course "Introduction to Quality Assurance" for all students. [12] }\end{array}$ \\
\hline $\begin{array}{l}\text { University } \\
\text { of } \\
\text { Jyväskylä }\end{array}$ & $\begin{array}{l}2015 \\
2021\end{array}$ & $\begin{array}{l}\text { (2015) nothing available [13] } \\
\text { (2021) nothing available [14] }\end{array}$ \\
\hline $\begin{array}{l}\text { University } \\
\text { of Lapland }\end{array}$ & 2016 & $\begin{array}{l}\text { Teaching methods include online teaching. } \\
\text { Online feedback system in Weboodi is used rarely [15] }\end{array}$ \\
\hline $\begin{array}{l}\text { LUT } \\
\text { University }\end{array}$ & 2015 & $\begin{array}{l}\text { Flexibility and personalisation are further enabled in the MIMM programme } \\
\text { with the possibility of students including credits from MOOCs (massive open } \\
\text { online courses). [16] }\end{array}$ \\
\hline $\begin{array}{l}\text { National } \\
\text { Defence } \\
\text { University }\end{array}$ & 2017 & $\begin{array}{l}\text { Moodle platform is used for teaching, exams, student feedback, internet } \\
\text { discussions and teaching material sharing. [17] }\end{array}$ \\
\hline $\begin{array}{l}\text { University } \\
\text { of Oulu }\end{array}$ & $\begin{array}{l}2010 \\
2018\end{array}$ & $\begin{array}{l}\text { (2010) Student information available online but scattered in various sites. [18] } \\
\text { (2018) On the whole, the information communication channels seemed } \\
\text { fragmented. The staff members get information via email and from the Notio, } \\
\text { SISU and TATU systems, and students use email, the Tuudo mobile } \\
\text { application, and the WebOodi and Moodle learning management } \\
\text { environments. [19] }\end{array}$ \\
\hline $\begin{array}{l}\text { Hanken } \\
\text { School of } \\
\text { Economics }\end{array}$ & $\begin{array}{l}2014 \\
2017\end{array}$ & $\begin{array}{l}\text { (2014) nothing available [20] } \\
\text { (2017) The four general learning goals, which are the same as for all the } \\
\text { English-language MSc and which have been developed into nine learning } \\
\text { objectives (LO), are available online. }\end{array}$ \\
\hline
\end{tabular}




\begin{tabular}{|c|c|c|}
\hline & & $\begin{array}{l}\text { Online teaching via the Moodle platform has also been developed as well as } \\
\text { video recordings of lectures and other internet-based teaching tools. [21] }\end{array}$ \\
\hline $\begin{array}{l}\text { University } \\
\text { of the Arts } \\
\text { Helsinki }\end{array}$ & 2018 & $\begin{array}{l}\text { Artsi intranet includes links for students and teachers to access some university } \\
\text { e-tools. } \\
\text { Teaching processes of the degree programs have defined by the IMS system } \\
\text { and they are published at the Atsi intranet. } \\
\text { Student feedback is collected with the WebOodi } \\
\text { Theatre school has an Office } 365 \text { platform for recording experiences } \\
\text { (successes \& failures) [22] }\end{array}$ \\
\hline $\begin{array}{l}\text { University } \\
\text { of Tampere }\end{array}$ & 2015 & $\begin{array}{l}\text { Learning environment development and quality management are handled by a } \\
\text { blended learning and online teaching working group. } \\
\text { Students have a positive attitude towards blended learning. } \\
\text { University web pages are not sufficient for quality system information sharing. } \\
\text { University web pages and the intranet give a weak support to the information } \\
\text { needs of the degree programs. [23] }\end{array}$ \\
\hline $\begin{array}{l}\text { Tampere } \\
\text { Technical } \\
\text { University }\end{array}$ & 2014 & $\begin{array}{l}\text { Technical support from the university is provided by four systems: ROCK, } \\
\text { POP, HOPS ja Kaiku. } \\
\text { ROCK is for teaching planning as well to provide course descriptions and } \\
\text { teaching. POP (Personoitu OpiskelijaPortaali) is for students to manage their } \\
\text { studies. HOPS is åersonal curriculum design. Kaiku is used for the student } \\
\text { feedback. } \\
\text { Oprek is used to manage the student records. } \\
\text { Several courses utilize the Moodle learning platform. Despite this most student } \\
\text { work is submitted by e-mail or even as a print. } \\
\text { Moodle is used to manage the thesis processes. [24] }\end{array}$ \\
\hline $\begin{array}{l}\text { University } \\
\text { of Turku }\end{array}$ & $\begin{array}{l}2015 \\
2017\end{array}$ & $\begin{array}{l}\text { (2015) The use of the intranet has resulted in quality-related information often } \\
\text { becoming indistinguishable from the units' regular operations, instructions and } \\
\text { guidelines. } \\
\text { Currently, intranet and public web pages are the primary sources for quality } \\
\text { documentation, } \\
\text { although some units still maintain distinct operations manuals. } \\
\text { One of the units provides high quality modern learning environments and } \\
\text { teaching methods, such as nationwide video-based courses, web-based courses, } \\
\text { experimental research courses and multi-professional clinical training. [25] } \\
\text { (2017) According to University policy, the intranet and the public web pages } \\
\text { are the primary forum for presenting quality documentation. The intranet is an } \\
\text { essential tool in standardizing and clarifying university operations. }\end{array}$ \\
\hline
\end{tabular}




\begin{tabular}{|l|l|l|}
\hline & & $\begin{array}{l}\text { Teachers are supported to develop their teaching, for instance by having } \\
\text { pedagogic training, increased intranet materials and examples of good practice. } \\
{[26]}\end{array}$ \\
\hline $\begin{array}{l}\text { University } \\
\text { of Vaasa }\end{array}$ & 2012 & $\begin{array}{l}\text { WebOodi online feedback system has been in use since } 2009 . \\
\text { Support procerss definitions are presented in the university portal. It includes } \\
\text { two systems: Ruori and Proppu. In Ruori the quality assurance has been } \\
\text { defined. Proppu is still under construction. } \\
\text { Moodel is used for curriculum and course design. [27] }\end{array}$ \\
\hline $\begin{array}{l}\text { Åbo } \\
\text { Akademi }\end{array}$ & 2016 & $\begin{array}{l}\text { The university uses websites, newsletters, the annual report and social media to } \\
\text { spread information about quality management. } \\
\text { Moodle is used to support student learning, e.g. by students receiving a } \\
\text { continuous response to their assignments. [28] }\end{array}$ \\
\hline
\end{tabular}

\section{CONCLUSION}

The pre-understanding about eLearning and the quality assurance in universities was based on the knowledge of roughly 20 years of digitalization developments in the Finnish universities. Adaptation of the Bologna practices with the quality assurance was taken into consideration as well. The results of this research show that within the quality system audit reports the quality assurance of eLearning operations is mostly missing.

The reality of the quality assurance of the eLearning provision in Finnish universities can be different to the results of this research. The reasons could be:

- the quality systems of the universities do not make any difference about the method of teaching: faceto-face, blended or totally online.

- the method of the quality system audits does not take any specific consideration about eLearning.

The conclusion here is, that it would require further research about the eLearning operations and about the applied quality assurance practices in Finnish universities in order to be able be certain of the situation.

\section{REFERENCES}

[1] Ministry of Education and Culture (2021) "Higher ed ucation institutions, science agencies, research insti tutes and other public research organisations". Avai lable: https://minedu.fi/en/heis-and-science-agencie s [23.5.2021]

[2] Ali-Vähälä, T. (2020) “Coping with diversity in high er education in European Higher Education Area -T he case of Quality Assurance”. JYU Dissertations 1 83. Jyväskylä. 98 p.
[3] Eurydice (2021) "Finland Quality Assurance in High er Education" Available: https://eacea.ec.europa.eu /national-policies/eurydice/finland/quality-assuranc e-higher-education_en [23.5.2021]

[4] Koponen E., (2008) “The development, implementat ion and use of e-learning: critical realism and desig n science perspectives", Tietojenkäsittelytieteiden 1 aitoksen sarja A-2008-8, Tampereen yliopisto, Tam pere 2008

[5] Ally M. (2003) "Foundations of Educational Theory for Online Learning", Theory and Practice of Onli ne Learning, Ed by Andersson \& Elloumi, Athabas ca University. Chapter 1, pp. 3-32.

[6] Hoikkala, T. \& Kiilakoski, T. (2018) "Digitalisaatio n pedagogiikka ja jatkuvan oppimisen ristiriidat" In Koulutusen Digiloikka, Teollisuuden palkansaajat TP ry, Helsinki. pp. 1253.

[7] Researching Virtual Initiatives in Education (2009) "Finnish Virtual University" (2009) Available: http ://www.virtualeducation.wiki/index.php/Finnish_V irtual_University [23.5.2021]

[8] Tikkanen, A. (2016) "Suomalaisten yliopistojen käy ttämät digitaaliset oppimisympäristöt", Informaatio teknologian tiedekunnan julkaisuja No. 24/2016, U niversity of Jyväskylä. 23 p.

[9] Bowen, G. A. (2009) "Document Analysis as a Qual itative Research Method”, Qualitative Research Jou rnal vol. 9, no. 2, pp. 27-40.

[10] Sursock, A., Buchheister A., Jauhiainen, S., Pirie, I ., Reindl, L., Ristimäki, S., Isoaho, K. \& Nordbla d, M. (2016) "Audit of Aalto University 2016", Fin nish Education Evaluation Centre Publications 25:2 
016. Juvenes Print - Suomen Yliopistopaino Oy, T ampere. $85 \mathrm{p}$.

[11] Riedler, P., Galevski, M., Koppinen, S., Maguire, K., Mahlamäki-Kultanen, S., Noorda, S., N., Seppä lä \& Saarilammi, M.-L. (2015) "Audit of the Unive rsity of Helsinki 2015", Finnish Education Evaluati on Centre Publications 2015:7. Juvenes Print - Suo men Yliopistopaino Oy, Tampere. $88 \mathrm{p}$.

[12] Aarrevaara, T., Werner, E., Althoff, G., Isotalo, J., Stephens, C., Saarilammi, M.-L. \& Isoaho, K. (201 5) "Audit of the University of Eastern Finland 2017 ", Finnish Education Evaluation Centre Publication s 10:2017, Juvenes Print - Suomen Yliopistopaino Oy, Tampere. $77 \mathrm{p}$.

[13] Seppälä, K., Björkroth, K., Karjalainen, P., Keräne n, H., Levä, K. \& Hiltunen, K. (2015) “Jyväskylän yliopiston auditointi 2015”, Finnish Education Eval uation Centre Publications 16:2015, Juvenes Print Suomen Yliopistopaino Oy, Tampere. 73 p.

[14] Hentilä, H.-L., Levä, K., Liikka, M., Toom, A., Hu usko, M. \& Nordblad, M. (2021) "Jyväskylän ylio piston auditointi" Finnish Education Evaluation Ce ntre Publications. 2:2021 85 p. [https://auditoinnit.k arvi.fi/auditoinnit/jyvaskylan-yliopiston-auditointi/ ?pdf-cid=13430\&pdf-aid=13430]

[15] Hildén, K., Mononen, K., Nykänen, M., Otala, L., Räsänen, P., Apajalahti, T. \& Moitus, S. (2016) "L apin yliopiston auditointi 2016", Finnish Education Evaluation Centre Publications 25:2016. Juvenes P rint - Suomen Yliopistopaino Oy, Tampere. $75 \mathrm{p}$.

[16] Pelik, R., Kantola, I., Myller, E., Simaškaitè, M., Ta ylor, J. \& Apajalahti, T. (2015) "Audit of Lappeenr anta University of Technology 2015”, Finnish Educ ation Evaluation Centre Publications 2015:15, Juve nes Print - Suomen Yliopistopaino Oy, Tampere. 7 $4 \mathrm{p}$.

[17] Luoma, M., Alkiora, P., Hiidenmaa, P., Käihkö, I., Levä, K., Frisk, T. \& Kajaste, M. (2017) "Maanpuo lustuskorkeakoulun auditointi”, Finnish Education Evaluation Centre Publications 8:2017, Juvenes Pri $\mathrm{nt}$ - Suomen Yliopistopaino Oy, Tampere. $86 \mathrm{p}$.

[18] Okko, P., Pirttilä, A., Ansala, L., Immonen, H., Uu sitalo, T. \& Saarilammi, M.-L. (2010) "Oulun ylio piston laadunvarmistusjärjestelmän auditointi”, Kor keakoulujen arviointineuvoston julkaisuja 6:2010. 7 $4 \mathrm{p}$.

[19] Hazelkorn, E., Abebe, R., Ahokallio-Leppälä, H., B ouillard, P., Korhonen-Yrjänheikki, K., Apajalahti, T. \& Tuurnas, A. (2018) "Audit of the University o f Oulu 2018”, Finnish Education Evaluation Centre
Publications 3:2018, Juvenes Print - Suomen Ylio pistopaino Oy, Tampere. $73 \mathrm{p}$.

[20] Salskov-Iversen, D., Kutschke, C., Melgin, T., Pirtti lä, A., Ward, M., Apajalahti, T. \& Seppälä, H. (201 4) “Audit of Hanken School of Economics 2014”, T he Finnish Higher Education Evaluation Council FI NHEEC. Tammerprint Oy, Tampere. 89 p.

[21] Lanarès, J., Raij, K., Suomela, I., Ward, M., Nordbl ad, M. \& Apajalahti, T. (2017) "Re-audit of Hanke n school of economics 2017". Finnish Education Ev aluation Centre Publications 7:2017. Juvenes Print - Suomen Yliopistopaino Oy, Tampere. 50 p.

[22] Hiillos, M., Halonen, P., Isotalo, J., Kuivalainen, M . Laakkonen, M. \& Isoaho, K. (2018) "Taideyliopis ton auditointi 2018", Finnish Education Evaluation Centre Publications 2:2018, Juvenes Print - Suome n Yliopistopaino Oy, Tampere. 89 p.

[23] Huttunen, J., Rasku-Puttonen, H., Artikka, T., Hild én, K., Järvinen, M.-R., Saarilammi, M.-L. \& Kajas te, M. (2015) "Tampereen yliopiston auditointi 201 5", Finnish Education Evaluation Centre Publicatio ns 11:2015, Juvenes Print - Suomen Yliopistopaino Oy, Tampere. $75 \mathrm{p}$.

[24] Mäki, M., Eskelinen, H., Hannula, O., Saxén, H., T oikka, M., Vuorinen, R., Mustonen, K. \& Kajaste, M. (2014) "2Tampereen teknillisen yliopiston audi tointi 2014", The Finnish Higher Education Evaluat ion Council FINHEEC. Tammerprint Oy, Tampere. $112 \mathrm{p}$.

[25] Niemelä, J., Crozier, F., Buettner, C., Derricott, D., Saarela, M., Moitus, S. \& Kajaste, M. (2015) “Audi t of the University of Turku 2015”, Finnish Educati on Evaluation Centre Publications 4:2015, Juvenes Print - Suomen Yliopistopaino Oy, Tampere. 66 p.

[26] Niemelä, J., Bladh, A., Galevski, M., Sarvaranta, L. , Moitus, S. \& Saarilammi, M.-L. (2017) "Re-Audit of the University of Turku 2017”, Finnish Educatio n Evaluation Centre Publications 16:2017, Juvenes Print - Suomen Yliopistopaino Oy, Tampere. 49 p.

[27] Niemelä, J., Kivistö, J., Lindblad, P., Räisänen, A., Wahlgrén, A., Holm, K. \& Saarilammi, M.-L. (201 2) "Vaasan yliopiston laadunvarmistusjärjestelmän auditointi”, Korkeakoulujen arviointineuvoston julk aisuja 3:2012.89 p.

[28] Bladh, A., Austenå, H., Koivumäki, K., Löfström, E., Stenkvist, R. \& Nordblad, M. (2016) "Auditerin g av Åbo Akademi 2016”, Finnish Education Evalu ation Centre. Publikationer 11:2016. Suomen Yliop istopaino Oy, Tampere. 71 p. 